The early memoirs of the Manchester Philosophical Society contain several papers by Wall, brief notes of whose lectures are preserved in MS. in the Radcliffe library and in private letters of the time; some of the latter are printed by $\mathrm{Mr}$. Gunther. Wall is described as a "learned, ingenious, and pleasing gentleman," who once had the honour of drinking tea with Dr. Samuel Johnson.

A contemporary of Wall's, James Higginbotham, of Magdalen Hall, afterwards James Price, of Guildford, was the last of the English alchemists, and killed himself after the exposure, by a committee of the Royal Society, of his pretensions to transmute mercury into gold.

From the closing years of the eighteenth century to the time of the foundation of the Aldrichian professorship, Oxford readerships in chemistry were held in succession by Dr. Thomas Beddoes (r788-93), best known as the founder of the "Pneumatic Institution" at Clifton, and the discoverer of Humphry Davy; and Dr. Robert Bourne, a fellow of Worcester, and an eminent medical man of his time. Indeed, practically all the readerships were held by medical men, and their teaching was largely directed to the needs of medicine.

In 1803 Dr. G. Aldrich endowed a professorship of chemistry. The first occupant of the chair was John Kidd, who held it from 1803 to 1822 . $\mathrm{He}$ is the author of two papers in the Phil. Trans., one on "Naphthaline, a peculiar substance ... produced during the decomposition of coal-tar"; the other on "The natural production of Saltpetre in the walls of subterraneous buildings," the saltpetre having been scraped from "the hoary walls" of the basement of the Ashmolean Museum in which Dr. Kidd and his family resided.
Dr. Kidd was succeeded by Dr. Charles G. B. Daubeny, a professor of botany to chemists, and a professor of chemistry to botanists, who held the chair for thirty-two years, when his "increasing duties at the Botanic Garden compelled him to resign his Chemical Professorship." The cellar at the Ashmolean, although, as Daubeny said, "notoriously unworthy of a great University, being dark, inconvenient, and confined," was afterwards occupied by the late Prof. Story-Maskelyne, who gave instruction there in chemical analysis. An incident connected with his tenancy of this basement is related by Mr. Gunther in a footnote with which this notice of a most interesting account of Oxford's relations to chemistry must conclude :-

Some workmen were employed to make some alterations to a wall when one of them drove his pick through into a small room that had evidently not seen the light of day for generations. They enlarged the aperture, and, on entering, found some bottles that appeared to them of extreme antiquity. Very naturally they tasted the contents and speculated on the possible origin of the long forgotten hoard. When eventually the discovery was reported to Maskelyne, then at the mineralogical department at the British Museum, he exclaimed, "They have broken into my cellar, the stupid idiots. If they had only looked at the other side they would have seen my new oak door." But what probably rankled in his mind was the thought that his own gin had impaired their clear vision.

Mr. Gunther's surmise cannot, however, be well founded, as the gin was reached only after the wall had been broken through. It was presumably the same wine cellar that Dr. Daubeny had vainly petitioned Convocation to improve for him.

\title{
Pons-Winnecke's Comet and its Meteor Shower.
}

By W. F. Denning.

A NEW comet was discovered by Jean Louis A Pons at Marseilles in June, I819, and it was observed during five weeks. From the observations obtained, Encke computed that the comet was revolving in an elliptical orbit, with a period of $205^{2}$ days, or 5.618 years. Nothing more was, however, seen of the object until nearly forty years afterwards, when Winnecke re-discovered it, and also re-determined its period of revolution. It has since been observed in 1869 , r875, I886, r892, r898, 1909, and 1915. During the last fifty years the planet Jupiter has somewhat disturbed the orbit of the comet, for the two objects made several near approaches. Two periods of the comet are nearly equivalent to one period of Jupiter, hence at alternate visits of the former to aphelion, as in about $1872,188_{3}, 1895$, and 1907 , the perturbations were considerable. These had the effect of lengthening the comet's period and bringing that section of its course which is nearest to the sun almost into conjunction with the earth's path at the end of June.

On June 28 , 1916, a meteoric shower of strikNo. 2679 , VOT. IO7] ing and abundant character was observed by the present writer at Bristol. It was first seen there at 10.25 p.m., and half an hour later it was also observed from Bournemouth and Birmingham. The sky was not very favourable, but at Bristol sixty-nine meteors were observed in about two hours, including twenty of the first magnitude, and the radiant point appeared to be diffused over the region of $\eta$ Ursæ Majoris, $\theta$ Boötis, and a little east. This position corresponded approximately with the radiant point computed for Pons-Winnecke's comet, and the date was also correct, so that an intimate association (or identity) of the two phenomena was suggested (see Monthly Notices of the Royal Astronomical Society for 19r6, vol. lxxvi., p. 742). The meteoric shower named is likely to be repeated, and on a more brilliant and abundant scale, on about June 27 next, for the comet will be very much nearer to the earth than it was in June, 1916. On that occasion the meteors were seen about ten months after the comet's nucleus had passed through perihelion, so that the stream of 
particles following in the comet's wake must have been something like $55^{\circ}$ million miles long. This need not, however, occasion great surprise, for observations have proved that in the case of the great Leonid stream of November the débris or meteoric particles are distributed completely around the orbit, which extends in its outer limits to beyond the path of the remote planet Uranus.

Formerly we had no special meteor shower to distinguish the midsummer period, but it is quite possible that in future years June may acquire a similar notoriety for meteors as that which has been long held by August and November, and should the new shower fully justify expectation it will in a certain measure prove a recompense for the lack of grand displays of meteors which has characterised the past thirty-five years. There were great storms of meteors in November, 1866 , I872, and I885, but the Leonids of Tempel's comet (1866) and the Andromedids of Biela's comet have failed to furnish a really brilliant display of first-class importance during more than the third of a century, and it seems difficult to predict the dates of great revivals, although the years 1933 and 1934 are likely to bring a considerable shower, if not a grand exhibition, of meteors at the middle of November.
Including the periodical comet of Pons-Winnecke, we now have six comets of which the orbits bear so striking and suggestive a similarity to those of rich meteoric streams that we may certainly conclude them to have the same derivative sources. There are also a number of other comets which furnish significant evidence that they are closely connected, if not identical, with active meteor showers. For example, the comet of Mechain-Tuttle seems to present conformity with a radiant point observed from $220^{\circ}+76^{\circ}$ from December 20 to 25 . The comet Lexell (I770) agrees with a radiant point in June at about $280^{\circ}-24^{\circ}$. The comet of 1739 agrees with a radiant point at $153^{\circ}+40^{\circ}$ from October $I_{4}$ to 22 , and the comet Denning (I88I) presents similar features of orbit to a meteor shower observed during the period July 25 to August 8 from a radiant at $303^{\circ}-10^{\circ}$.

There are many other instances in which cometary and meteoric accordances may be assumed with a fair degree of probability, yet when we consider the large number of orbits now definitely computed for comets and meteor streams we are bound to admit that chance coincidences must sometimes occur, and that it is difficult, except in special cases, to select the genuine instances of agreement.

\section{Obituary.}

Prof. L. C. Miall, F.R.S.

THE death of Prof. Miall, announced in our columns last week, removes from the world a man who stood in natural history eminent in a position of his own, in education as one of the most sane and enlightened reformers of his time, and in personality one of the truly great among men.

Louis Compton Miall was born in 1842 , the son of a Congregational minister in Bradford. After his early education at Silcoates he entered the teaching profession as an assistant master, but was soon tempted to accept the curatorship of the newly founded Literary and Philosophical Society of Bradford, where he developed a keen interest in geology and palæontology. A little later he was appointed to the curatorship of the Museum of the Leeds Philosophical and Literary Society, and in 1876 , two years after the foundation of the Yorkshire College of Science, he was appointed as its first professor of biology, a position which he continued to hold in the University of Leeds until his retirement in 190\%. With Sir Edward Thorpe, the late Sir Arthur Rücker, and Prof. A. H. Green he was one of the four scientific pioneers of university education in Yorkshire. He held the Fullerian professorship of physiology in the Royal Institution, 1904-5, was president of Section D (Zoology) of the British Association at the Toronto meeting in 1897 , and president of the Education Section at Dublin in 1908. He was No. 2679, voL. IO7] elected a fellow of the Royal Society in 1892 , and made an honorary D.Sc. of Leeds in 1904 .

On his retirement from Leeds in 1907 Prof. Miall took up his residence at Letchworth, within easy reach of Cambridge and of the British Museum, and he continued active in writing and teaching. In 1918 , soon after the death of his gifted wife, to whom he was married in 1870 , he returned to his native county, residing at Ben Rhydding. For some time he maintained an active interest in his books, and he left practically complete a work on "Garden-craft in the Past." Latterly his health failed somewhat, but almost until his death he retained wonderful vigour of mind and intellectual interest. In the middle of January he had a slight paralytic stroke, followed by a second, which left him in a weak state. From then his strength slowly ebbed, and he passed away peacefully, without suffering, in the house of his daughter, Mrs. Harold Wager, at Leeds.

To those who did not know him it is scarcely possible to give an adequate idea of the kind and strength of the influence which Prof. Miall exercised, or of the veneration in which he was held wherever his labours lay. In attempting to describe any section of his work there arises at once the memory of the man himself, his arresting personality, the scale and strength of his principles of heart and mind, his austere simplicity and perfect sincerity, his deliberate judgment, the comprehensiveness and sanity of his mental atti- 